Syntax Literate: Jurnal Ilmiah Indonesia p-ISSN: 2541-0849

e-ISSN: 2548-1398

Vol. 7, No. 1, Januari 2022

\title{
EMOSI NEGATIF, SEBUAH STUDI EKSPLORATORI DENGAN CRITICAL INCIDENT TECHNIQUE DALAM SITUASI RIGHTSIZING
}

\section{Fuad Firmansyah}

Magister Manajemen, Universitas Airlangga, Surabaya, Indonesia

Email: fuad.firmansyah87@gmail.com

\begin{abstract}
Abstrak
Penelitian ini bertujuan untuk mengetahui efek rightsizing pada emosi para executor yang menjadi penyampai keputusan pemutusan hubungan kerja (PHK) dalam proses rightsizing. Executor yang dimaksud pada penelitian ini adalah para manajer departemen sumber daya manusia yang bertugas untuk menyampaikan keputusan perusahaan untuk memutus hubungan kerja kepada para karyawan. Penelitian ini menggunakan pendekatan kualitatif. Metode pengumpulan data yang dipakai adalah Critical Incident Technique (CIT), yaitu mengumpulkan berbagai critical incident dari subyek penelitian untuk mendapatkan informasi mengenai fenomena yang diteliti. Data diperoleh dari hasil wawancara semi terstruktur kepada 6 orang manajer sumber daya manusia yang bekerja pada perusahaan manufaktur. Setelah dilakukan eksplorasi hasil wawancara, diketahui bahwa para responden mengaku mengalami beberapa emosi negatif setelah menyampaikan berita pemutusan hubungan kerja kepada para karyawan. Emosi negatif yang dialami yaitu rasa bersalah (guilt), rasa sedih (sad), dan rasa terganggu (annoyed). Emosi negatif yang muncul akibat proses rightsizing terhadap para penyampai keputusan ini harus dihindari dikarenakan jika emosi negatif tersebut berdampak buruk pada kinerja jika tidak segera diatasi. Dampaknya dapat meluas hingga dapat menyebabkan turunnya produktivitas dan rasa tidak aman. Tindakan preventif untuk menghindari emosi negatif ini dapat dilakukan dengan memberikan pengertian sebelumnya seperti membina dan menjelaskan bahwa keputusan yang diambil perusahaan merupakan keputusan yang terbaik.
\end{abstract}

Kata Kunci: rightsizing; emosi negatif; perampingan organisasi

\section{Abstract}

This study aims to determine how rightsizing affects the emotions of the executors who convey the decision to terminate employment in the rightsizing process. The executors referred to in this study are managers of human resources department who inform the company's decision to terminate employment. This research uses a qualitative approach. The data collection method used is Critical Incident Technique (CIT), which collects various critical incidents from research subjects to obtain information about the phenomenon under study. Data were collected from semi-structured interviews with 6 human resource managers who work in manufacturing companies. After exploring the results of the interviews, it was found that the respondents claimed to have experienced several negative emotions

$\begin{array}{ll}\text { How to cite: } & \text { Firmansyah. F (2022) Emosi Negatif, Sebuah Studi Eksploratori dengan Critical Incident Technique dalam } \\ & \text { Situasi Rightsizing. Syntax Literate: Jurnal Ilmiah Indonesia, 7(1). http://dx.doi.org/10.36418/Syntax- } \\ & \text { Literate.v7i1.1889 } \\ \text { E-ISSN: } & \text { 2548-1398 } \\ \text { Published by: } & \text { Ridwan Institute }\end{array}$


after conveying the decision of the termination of employment to employees. The negative emotions they experienced were guilt, sadness, and annoyed feelings. Negative emotions that arouse as a result of the rightsizing process for those who conveyed this decision must be avoided because if these negative emotions persist, they would have a negative impact on performance if this problems are not solved immediately. The impact can be widespread to the point of causing decreased productivity and job insecurity. Preventive action to avoid negative emotions can be done by providing prior understanding such as fostering and explaining that the decisions made by the company are the best decisions.

Keywords: rightsizing; negative emotions; employment termination

Received: 2021-12-20; Accepted: 2022-01-05; Published: 2022-01-15

\section{Pendahuluan}

Departemen sumber daya manusia di setiap perusahaan berfungsi untuk menangani berbagai masalah pada ruang lingkup karyawan untuk menunjang aktifitas dalam perusahaan tersebut. Begitupun ketika perusahaan mengalami masalah maka departemen sumber daya juga harus secara aktif terlibat apalagi dalam era persaingan yang sangat ketat. Dalam era sekarang di mana persaingan sangat ketat dan inovasi sangat di perlukan, maka salah satu syarat mutlak yang harus dimiliki perusahaan adalah keunggulan bersaing (competitive advantage).

Menurut (Porter \& Maulana, 1980), ada 3 strategi bersaing generik yaitu low cost, diferensiasi dan fokus. Stategi low cost adalah strategi keunggulan biaya dimana untuk memenangkan persaingan sebuah perusahaan harus bisa mengatur biayanya sehingga mampu bersaing dengan para pesaingnya. Untuk mencapai hal tersebut perusahaan mengambil langkah-langkah yang berorientasi pada efisiensi dan pengendalian biaya yang sangat ketat sehingga biaya per unit satuan menjadi lebih rendah dan mampu bersaing dengan para pesaing. Namun dengan semakin meningkatnya persaingan dari hari ke hari, maka kontrol internal kadang tidaklah cukup dan hal itu mengharuskan perusahaan untuk melakukan cost reduction dengan cara lain dan fokus terhada perampingan organisasi yang diharapkan dapat mengurangi biaya produksi.

Perusahaan akan selalu mencari formasi yang tepat, orang yang sesuai, serta waktu yang tepat dalam setiap posisi atau jabatan, karena organisasi dapat berjalan secara efektif dan efisien apabila didukung oleh sumber daya manusia yang mempunyai kualitas dan kompetensi yang memadai serta diiringi dengan jumlah yang optimal. Unit kerja yang tidak didukung dengan jumlah SDM yang memadai akan sulit untuk mencapai kinerja yang optimal karena individu merasakan pekerjaan yang dilakukannya terlalu berat (Hossain \& Taylor, 1998). Sehingga ketika persaingan sangat ketat maka perusahaan dituntut untuk bergerak cepat dan segera melakukan optimalisasi.

Perampingan organisasi atau rightsizing menjadi pilihan perusahaan ketika kondisi persaingan sudah cukup tinggi dan perusahaan harus melakukan langkahlangkah yang perlu untuk segera keluar dari masalah tersebut. Manajemen perusahaan yang luas dan kompleks sudah tidak mungkin lagi dipertahankan untuk bersaing secara 
kompetitif. Umumnya langkah perampingan (rightsizing) yang dilakukan oleh perusahaan adalah dalam rangka menyehatkan kembali perusahaan dalam rangka menciptakan "low cost production." Hal ini harus dilakukan perusahaan karena stabilitas dan prediktabilitas bisnis telah digantikan oleh ketidakpastian, kompleksitas dan persaingan yang semakin intens (Cameron, Freeman, \& Mishra, 1993).

Rightsizing selain bertujuan untuk merubah struktur perusahaan, juga diharapkan dapat mempertahankan tingkat produktifitas dari perusahaan itu sendiri dan hal itu dilakukan dengan mengurangi jumlah tenaga kerja yang dianggap sudah tidak efektif. Bahkan mungkin pengurangan jumlah unit operasi juga perlu dilakukan. Para survivors, atau pegawai yang tidak terkena pemutusan hubungan kerja, tentu merespon rightsizing tersebut dengan cara berbeda. Menurut teori stress dari (Lazarus \& Folkman, 1986) respon-respon tersebut dipengaruhi oleh kepercayaan (trust), rasa adil, adanya job redesign dan pemberian kewenangan (empowerment). Hal pertama yang diharapkan dari rightsizing tentunya adalah organisasi menjadi lebih sederhana dan semakin efektif dan efisien. Tentu ada yang sejalan dengan rencana perusahaan tersebut, terutama mereka yang suka tantangan sehingga ketika organisasi semakin sederhana dan tugas menjadi semakin beragam, mereka tidak keberatan dan justru menganggap hal tersebut sebuah tantangan yang menarik dan harus ditaklukkan. Namun sebaliknya untuk para pekerja yang tidak siap akan mengalami dampak negatif.

Mempertimbangkan hal tersebut maka setelah melakukan rightsizing perusahaan harus secara cermat menjaga karyawan yang bertahan agar tidak mengalami job insecurity, yaitu menurut (Greenhalgh \& Rosenblatt, 1984) adalah suatu kondisi ketidakberdayaan seseorang secara terus menerus dalam mewujudkan keinginannya pada sebuah situasi kerja yang menakutkan. Karena itu perlu membangun kembali kepercayaaan terhadap suatu organisasi atau perusahaan yang telah melakukan rightsizing.

Maka dalam berbagai kasus tentang rightsizing ini telah banyak yang meneliti tentang dampak dari korban rightsizing dan beberapa mengenai para survivor atau orang yang bertahan, selanjutnya untuk orang yang bertahan setelah proses rightsizing ini akan disebut survivor. Diantara para survivor tersebut bahkan ada yang menjadi salah satu eksekutor atau penyampai keputusan hubungan kerja ke pekerja lain dalam situasi rightsizing tersebut. Para staff dan atau manajer departemen sumber daya adalah umumnya menjadi bagian survivor sekaligus menjadi penyampai langsung keputusan tersebut.

Departemen sumber daya manusia dalam suatu perusahaan yang melakukan rightsizing tentu akan mengalami yang dialami oleh para survivor lainnya, namun mereka mendapat beban lebih karena selain mengalami restrukturisasi organisasi yang sama mereka juga mewakili perusahaan untuk menyampaikan proses tersebut langsung kepada setiap karyawan. Segala proses sebelum dan sesudah proses rightsizing tersebut akan sangat memerlukan keterlibatan departemen sumber daya.

Menurut (Frost, 2003) tanpa mengenali emosi bagaimanapun Organisasi tidak bisa menyelesiaikan penyebab masalah secara efektif dan manusiawi. Keadaan setelah 
rightsizing tentu akan sangat tidak ideal terutama untuk para pekerja departemen sumber daya tersebut, karena umumnya para pekerja yang terkena dampak rightsizing akan menyalahkan departemen ini dan tidak mau tahu proses ini. Hal tersebut tentu berdampak pada emosi mereka karena pada umumnya orang akan ragu untuk membagi berita buruk dibandingkan dengan berita baik (Dibble \& Levine, 2010); (McGlone \& Batchelor, 2003). Oleh karena itu, emosi para penyampai keputusan tersebut perlu diperhatikan agar tidak mengarah ke negative emotion.

Kondisi negative emotion harus dihindari, terutama untuk departemen sumber daya yang tidak hanya sebagai pihak yang terkena dampak, namun juga menjadi pelaku yaitu sebagai wakil dari perusahaan untuk menyampaikan kepada para pekerja yang terkena dampak rightsizing. Apalagi mereka harus berhadapan baik secara bersamasama maupun pribadi dalam penyampaian pemutusan hubungan kerja. Berdasarkan latar belakang masalah yang telah diungkapkan di atas, maka perumusan masalah yang diajukan dalam penelitian ini adalah untuk mengetahui apa yang terjadi pada emosi para executor yang menjadi penyampai keputusan pemutusan hubungan kerja dalam proses rightsizing.

Penelitian terdahulu yang berkaitan dengan dengan negatif emotion, rightsizing dan para survivor salah satunya adalah artikel yang terdapat pada (Grace, 2007) berjudul "How Embarrassing! An Exploratory Study of Critical Incidents Including Affective Reactions". Dalam penelitian ini, Debra Grace membahas tentang rasa malu menggunakan CIT. Data dikumpulkan dari 44 usaha jasa yang berbeda dengan total jumlah 166 responden. Persamaan dengan penelitian ini adalah dalam fokusnya terhadap rasa malu yaitu salah satu negatif emotion dan metodologi yang dipakai. Sedangkan perbedaan dengan penelitian ini adalah fokus penelitian yang menekankan pada para survivor yang menyampaikan keputusan dalam situasi rightsizing.

\section{A. Emosi Negatif}

Menurut (Izard, 1991) emosi mengacu pada perasaan yang dialami individu, dan yang kemudian membantu memotivasi, mengorganisir dan mengarahkan persepsi, pikiran dan tindakan. Emosi kemudian diteliti lebih jauh oleh (Jenkins \& Oatley, 1996) dan mengartikan emosi sebagai sebuah fenomena yang menyebabkan kondisi mental, perubahaan fisik, muka dan suara dan biasanya diikuti oleh tindakan.

Carlos Thaylor (1995) berpendapat bahwa emosi masuk secara mendalam siapa diri kita, apa yang kita alami, dan apa yang penting bagi kita. Dan dari definisi-definisi tersebut peneliti menyimpulkan emosi adalah perasaan terhadap sesuatu baik senang atauapun sedih, sehingga jika dikaitkan dengan hal negatif maka perasaan terhadap sesuatu bersifat negatif seperti sedih, rasa bersalah, malu dan lain-lain.

\section{B. Rightsizing}

Rightsizing dulu disebutkan sebagai downsizing, menurut (Cameron, 1994) rightsizing merupakan serangkaian aktifitas yang dilakukan oleh pihak manajemen guna meningkatkan efisiensi, produktifitas dan tingkat kompetisi organisasi. 
Sedangkan Kozlowski dkk. (1993) mengartikan rightsizing sebagai keputusan manajemen yang disengaja untuk mengurangi tenaga kerja guna memperbaiki kinerja organisasi. Menurut (Cameron et al., 1993), Pelaksanaan strategi rightsizing memiliki tiga strategi yaitu:

1. A workforce reduction strategy: Memfokuskan pada penguragan tenaga kerja seperti pension dini, pengurangan jumlah pegawai, pemberhentian sementara

2. An organization redesign strategy. Memfokuskan pada pengurakan jumlah pekerjaan daripada pengurangan jumlah tenaga kerja, seperti, mengapus fungsi kerja yang tidak efisiean, mengurangi level hirarkis

3. The systemic change strategy. Yaitu merupakan perubahan yang meliputi semua aspek organisasi termasuk proses desain, metode produksi, hubungan dengan konsumen.

Dari ketiga strategi tersebut tambah bahwa rightsizing bisa dilakukan dengan mengkombinasikan ketiga strategi tersebut. Dan menurut defisi-defini diatas rightsizing bisa disimpulkan adalah pendekatan untuk mengurangi staf di mana jabatan-jabatan diurutkan menurut prioritas untuk mengidentifikasi dan menghilangkan pekerjaan yang tidak perlu.

\section{Emosi negative dalam situasi rightsizing}

Emosi negatif mempengaruhi kenyamanan para survivor dan employee engagement. Dalam penelitiannya, (Saks, 2019) menyebutkan employee engagement berdampak positif untuk organisasi. Sehingga apabila emosi tersebut berdampak negatif dan mempengaruhi rasa aman dan nyaman seorang pekerja dan bisa berdampak pada keinginannya untuk berhenti.

Dalam situasi rightisizing di mana perusahaan melakukan perubahaan secara terstruktur dan terjadi perubahaan secara signifikan kondisi perusahaan maka hal tersebut akan sangat berkaitan dengan emosi pekerja tersebut. Hal itu diperparah apabila pekerja tersebut juga ikut ambil bagian dalam pengambilan keputusan dan menyampaikan langsung kepada pekerja yang terdampak rightsizing tersebut. Karena menurut (Weakland, 2001) salah satu yang harus diperhatikan organisasi dalam pelaksanaan rightsizing adalah keterlibatan pegawai. dan apabila ketidaknyamanan muncul apabila ikut terlibat karena emosi yang negatif seperti rasa bersalah atau malu maka hal bisa berdampak pada hal yang lebih jauh baik performa karyawan tersebut hingga keinginan untuk berhenti.

\section{Metode Penelitian}

Penelitian ini menggunakan pendekatan kualitatif. Menurut (Moleong, 2013) penelitian kualitatif adalah penelitian yang memiliki fokus pada pemahaman fenomena yang terjadi dan berkaitan dengan subyek penelitian, misalnya perilaku, persepsi, motivasi dan tindakan dengan cara deskriptif atau penjelasan melalui kata-kata dan bahasa pada suatu kontesk tertentu. 
Penelitian ini dilakukan berdasarkan fenomena yang ada dan berusaha mendeskripsikan fenomena tersebut sesuai dengan gejala atau keadaan yang terjadi, maka penelitian ini menggunakan pendekatan deskriptif kualitatif. Jenis penelitian deskriptif kualitatif ini dimaksudkan untuk memperoleh informasi mengenai keadaan mental subyek penelitian, yaitu para Human Resource Managers dari beberapa perusahaan manufaktur yang berperan sebagai penyampai keputusan pemutusan hubungan kerja dalam situasi rightsizing atau pengurangan staff secara permanen.

Metode pengumpulan data yang dipakai dalam penelitian ini adalah Critical Incident Technique (CIT), yaitu mengumpulkan berbagai critical incident dari subyek penelitian untuk mendapatkan informasi mengenai fenomena yang diteliti. Critical incident itu sendiri menurut (Flanagan, 1954) adalah segala aktifitas manusia yang dapat diamati dan memberi kontribusi yang signifikan untuk memecahkan masalah yang sedang dihadapi. Teknik ini dipilih karena merupakan teknik yang sesuai bagi penelitian ini, di mana fokusnya adalah mendeskripsikan fenomena, mengumpulkan fakta (insiden), mengidentifikasi isu-isu yang terjadi dan melakukan evaluasi guna mendapat solusi dari masalah utama.

Pengumpulan data pada penelitian ini dilakukan dengan wawancara atau seperti yang dijelaskan oleh (Usman et al., 2008) yaitu tanya jawab yang melibatkan dua orang atau lebih secara langsung atau verbal yang bertujuan untuk mendapat data dari sumber utama dan menguji hasil pengumpulan data. Wawancara dilakukan dengan cara semi terstruktur di mana responden akan diberi pertanyaan yang yang telah penulis buat sebelumnya, kemudian penulis juga akan mengajukan pertanyaan berdasarkan jawaban dari responden.

Sampel yang dipilih dalam penelitian ini adalah 6 orang Human Resource Managers dari beberapa perusahaan manufaktur di Indonesia. Seluruh responden merupakan pihak yang terlibat langsung dan berperan sebagai penyampai keputusan pemutusan hubungan kerja dalam situasi rightsizing atau pengurangan staff.

Wawancara dalam penelitian ini akan dilakukan terhadap setiap responden secara one -on-one dan tidak bersamaan. Hal ini dilakukan agar responden merasa leluasa dalam menyampaikan pendapat dan menjawab pertanyaan. Key informant diminta untuk menjawab daftar pertanyaan tentang negative emotion dan apa yang mereka perbuat setelah terlibat dalam proses rightsizing. Beberapa pertanyaan yang akan diajukan adalah sebagai berikut: 


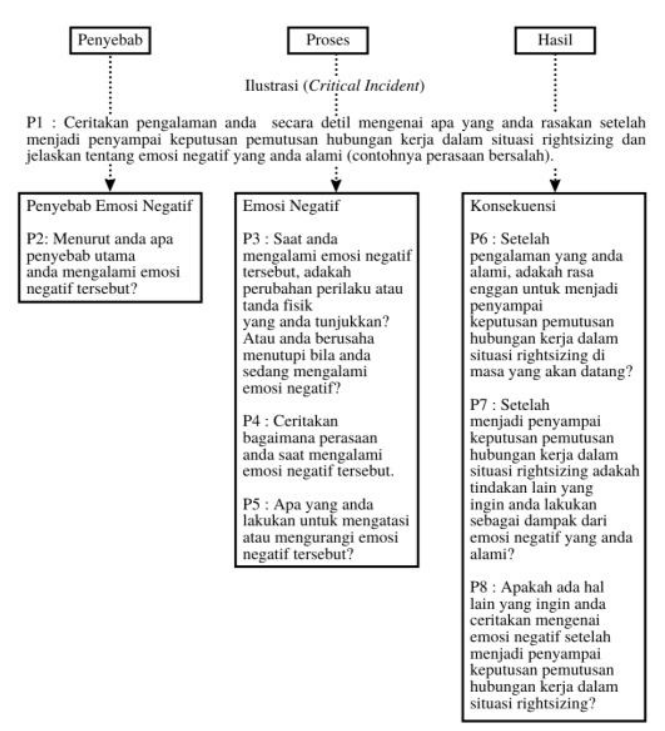

Gambar 1

Analisis Fungsional Emosi Negatif

Jawaban dari wawancara tersebut akan menghasilkan data primer yang selanjutnya digunakan untuk mengambil kesimpulan tentang perilaku yang bersangkutan dan dampak apa yang timbul setelah melakukan proses rightsizing di perusahaan tempat mereka bekerja.

Teknik analisis data yang dipakai dalam penelitian ini adalah penilaian hasil transkrip dari wawancara, analisis, dan interpretasi data. Hasil dari interpretasi data tersebut digunakan untuk menarik kesimpulan tentang masalah yang diteliti dan dampaknya serta memberi saran untuk memecahkan masalah. Langkah terakhir yang perlu dilakukan adalah mengevaluasi apakah saran yang diberikan mempunyai kontribusi besar dalam mengurangi masalah dan dapat mencegah timbulnya masalah baru.

Tahap terakhir dari penelitian ini adalah penarikan kesimpulan. Peneliti akan menarik kesimpulan dari hasil pengolahan data penelitian hasil wawancara, dan membandingkan dengan literatur. Kesimpulan dari penelitian ini akan berupa emosi negatif yang dialami para responen, perilaku mereka dan dampak yang akan timbul setelah terlibat langsung dalam proses rightsizing perusahan.

\section{Hasil Dan Pembahasan}

Wawancara dilakukan terhadap 6 orang staff human resource development yang bekerja pada 5 perusahaan yang berbeda di Indonesia. Wawancara dilakukan via telepon dengan mengajukan 8 pertanyaan yang telah disusun dengan tujuan meneliti lebih lanjut emosi negatif dan dampak yang mungkin timbul setelah responded menjadi penyampai keputusan pemutusan hubungan kerja dalam situasi rightsizing.

Karakteristik responden pada penelitian ini didefinisikan berdasarkan jenis kelamin, usia, pendidikan terakhir serta masa kerja. Responden pada penelitian ini adalah 2 orang laki-laki dan 4 orang perempuan. 5 orang memiliki pengalaman kerja 
selama 11 hingga 20 tahun dan satu di antaranya memiliki pengalaman kerja selama 21 hingga 30 tahun. Pada kategori usia, 1 orang responden berusia antara 31-40 tahun, 4 orang berusia 41-50 tahun, dan 1 orang memiliki rentang usia 51-60 tahun. Sebagian besar responden dalam penelitian ini mempunyai background pendidikan terakhir S1 atau sarjana. Hanya satu orang responden yang berpendidikan S2 atau master dan tidak ada responden yang melanjutkan pendidikan hingga tingkat S3.

Penelitian ini merupakan suatu studi eksploratori mengenai emosi negatif yang dialami para penyampai pemutusan hubungan kerja dan bagaimana dampaknya bagi mereka. Studi ini memiliki critical event yaitu rightsizing yang terjadi pada suatu perusahaan, di mana pada umumnya akan menyebabkan adanya perampingan perusahaan dengan cara mengurangi pegawai sehingga terjadi pemutusan hubungan kerja.

Pada pembahasan hasil penelitian ini, penulis membagi hasil penelitian dalam dua bagian. Bagian yang pertama adalah penjelasan tentang emosi negatif yang timbul pada diri responden saat mereka menjadi penyampai keputusan pemutusan hubungan kerja dan apa yang menyebabkan munculnya emosi-emosi negatif tersebut. Bagian ini juga menjelaskan tentang proses yang dihadapi saat menyampaikan keputusan pemutusan hubungan kerja. Hal ini berkaitan dengan perilaku penyampai keputusan dan apa yang dirasakan saat proses tersebut berlangsung. Selanjutnya bagian kedua berisi tentang bagaimana mereka mengatasi emosi negatif yang timbul dan bagaimana dampaknya bagi pekerjaan mereka.

\section{A. Emosi Negatif yang Muncul Pada Penyampai Keputusan Pemutusan Hubungan Kerja}

(Oatley \& Jenkins, 1992) menyatakan bahwa emosi adalah sebuah fenomena yang menyebabkan kondisi mental, perubahaan fisik, muka dan suara dan biasanya diikuti oleh tindakan. Ada beberapa jenis emosi yang dapat dialami, salah satu di antaranya adalah emosi negatif. Emosi negatif bisa muncul pada siapa saja dan kapan saja dan seringkali terjadi sebagai dampak dari suatu kejadian yang tidak menyenangkan. Emosi negatif ini dapat disebabkan oleh beberapa hal, seperti faktor internal atau dari dalam diri sendiri dan faktor eksternal atau yang dipengaruhi oleh tindakan orang lain. (Dube, Belanger, \& Trudeau, 1996) menambahkan bahwa emosi negatif bisa juga disebabkan oleh faktor situasional, di mana emosi timbul setelah sesuatu di lingkungan sekitar terjadi.

Dari hasil wawancara keenam orang responden, dapat dikatakan bahwa emosi negatif yang timbul adalah emosi negatif yang dipengaruhi oleh faktor internal, yaitu diri sendiri. Para responden mengaku bahwa mereka mengalami perasaan bersalah (guilt) setelah menjadi penyampai keputusan pemutusan hubungan kerja. Perasaan bersalah ini muncul pada awal karir mereka menjadi Human Resource Manager. Walaupun sebagian besar responden menyatakan bahwa setelah menjadi penyampai keputusan selama beberapa tahun mereka sudah mulai terbiasa, ada beberapa responden yang menyatakan bahwa mereka masih mengalami dampakdampak negatif yang timbul setelah mereka menyampaikan keputusan kepada 
pegawai yang akan diPHK, bahkan salah satu di antara mereka merasakan gejalagejala fisik seperti demam dan sakit kepala setelah menjadi penyampai keputusan pemutusan hubungan kerja tersebut.

Emosi negatif yang dominan dialami para penyampai keputusan pemutusan hubungan kerja pada awal karir adalah rasa bersalah (guilt). Para responden mengaku awalnya mereka merasa bersalah setelah menjadi penyampai keputusan tersebut.mereka umumnya merasa tidak tega untuk menyampaikan keputusan tersebut, terlebih lagi jika mereka memikirkan apa yang mungkin terjadi selanjutnya terhadap karyawan yang akan diberhentikan dari pekerjaan. Menurut para responden, rasa bersalah ini akan semakin kuat apabila mereka tidak bisa melakukan pemutusan hubungan kerja dengan tepat, contohnya bila pemutusan hubungan kerja dilakukan tidak sesuai dengan regulasi namun pihak top management tetap menginginkan keputusan tersebut. Hal ini dianggap tidak normatif dan kurang manusiawi, sehingga para Human Resource Manager merasa bersalah sudah menjadi penyampai keputusan tersebut.

Emosi negatif lain yang dirasakan oleh para responden saat menjadi penyampai keputusan pemutusan hubungan kerja adalah rasa sedih ( $\mathrm{sad}$ ). Dalam penelitian ini, sebagian besar responden adalah perempuan dan mereka mengungkapkan bahwa dalam melaksanakan tugas sebagai seorang Human Resource Manager mereka seringkali melibatkan perasaan sehingga rasa kasihan akan lebih mudah muncul. Mereka cenderung berpikir panjang tentang apa yang akan terjadi terhadap pegawai yang akan diberhentikan masa kerjanya. Apakah orang tersebut menjadi tulang punggung keluarga dan apakah keadaan finansial orang tersebut bisa membaik setelah dikeluarkan dari perusahaan. Perasaan sedih yang timbul pada para penyampai keputusan merupakan refleksi dari rasa empati mereka sesama manusia. Tak jarang mereka memposisikan diri sebagai orang yang akan diberhentikan sehingga emosi sedih tersebut semakin terasa.

Selain rasa bersalah dan rasa sedih, para responden menyatakan bahwa mereka terkadang merasa kesal dan terganggu (annoyed). Para Human Resource Manager mengatakan bahwa mereka akan merasa kesal dan teranggu apabila pegawai yang akan diberhentikan tidak menyadari kesalahan yang dilakukannya sehingga ia tidak patut dipertahankan di perusahaan tersebut. Hal ini membuat jengkel para penyampai keputusan pemutusan hubungan kerja karena terkadang mereka merasa mendapatkan serangan balik dari karyawan yang akan dirumahkan.

Sesuai dengan yang dikatakan oleh (Jenkins \& Oatley, 1996) bahwa emosi dapat mempengaruhi kondisi mental, perubahaan fisik, dan muka, beberapa responden mengaku bahwa mereka mengalami perubahan-perubahan tersebut. Salah satu perubahan perilaku yang terjadi setelah menjadi penyampai keputusan pemutusan hubungan kerja adalah mereka menjadi lebih pendiam, murung, dan nafsu makan menurun. Sebagian dari mereka ada yang dapat menutupi perubahan perilaku dan mimik muka ini, namun sebagain mengaku bahwa mereka tetap menunjukkan perubahan tersebut tanpa menutupi. 


\section{B. Cara Mengatasi Emosi Negatif yang Timbul Setelah Menjadi Penyampai Keputusan Pemutusan Hubungan Kerja}

Para responden memang mengaku mengalami beberapa emosi negatif setelah menjadi penyampai keputusan pemutusan hubungan kerja, namun seiring berjalannya waktu mereka mengatakan bahwa emosi-emosi tersebut lambat laun berkurang. Dengan pengalaman kereja sebagai Human Resource Manager selama belasan bahkan puluhan tahun, mereka dapat mencegah mengatasi emosi negatif yang mungkin timbul setelah menjadi penyampai keputusan.

Untuk mengatasi emosi negatif, pada responden menyatakan bahwa sebelum menjadi penyampai keputusan pemutusan hubungan kerja, mereka harus memastikan dan meyakinkan diri sendiri bahwa ada alasan yang kuat sehingga pegawai memang pantas untuk diberhentikan. Sebelum mengambil keputusan untuk memutus hubungan kerja seorang pegawai, sebagian besar responden menyatakan bahwa mereka telah melakukan tindakan preventif dengan cara membina, melakukan coaching serta mencari akar permasalahan dan mengusahakan agar karyawan tersebut bisa bertahan. Saat pegawai sudah dibina namun tetap tidak bisa merubah situasi, artinya mereka tetap merugikan perusahaan, maka pemutusan hubungan kerja harus dilakukan dan dalam situasi seperti ini para Human Resource Manager menyatakan bahwa rasa bersalah mereka akan berkurang.

Usaha lain yag dilakukan untuk mengurangi emosi negatif dalam menyampaikan keputusan pemutusan hubungan kerja adalah dengan memilih metode penyampaian yang sesuai dengan karakter pegawai yang akan diberhentikan. Cara menyampaikan keputusan bisa bermacam-macam seperti harus frontal dan to the point atau harus dengan halus. Selain itu, metode penyampaian juga harus komprehensif, artinya penyampai keputusan harus bisa menyampaikan alasan kuat mengapa keputusan tersebut harus diambil dan memberikan dukungan moral. Salah satu bentuk dukungan moral yang diberikan bisa berupa penyampaian informasi tentang hak-hak yang akan diberikan kepada pegawai pasca pemutusan hubungan kerja dan meyakinkan mereka bahwa ini adalah keputusan yang paling baik.

Salah satu responden menyatakan bahwa ia memiliki metode lain untuk meredam rasa bersalah. Untuk mengurangi emosi negatif, responden tersebut biasanya menunda melanjutkan meeting dengan pegawai yang akan diberhentikan dengan tujuan memberi waktu untuk berpikir dan mempersiapkan diri sehingga harapannya di pertemuan selanjutnya pegawai sudah lebih siap dan dapat menerima keputusan.

Selain melakukan pendekatan dan komunikasi dengan pegawai yang akan diberhentikan dari pekerjaan, para responden juga melakukan pendekatan kepada orang-orang terdekat pegawai tersebut. Mereka mengajak teman terdekat pegawai di kantor dengan tujuan bisa membantu menyemangati pegawai yang akan diberhentikan dan membesarkan hati pegawai tersebut. Salah satu di antara 6 orang responden bahkan mengaku ia sempat mendatangi rumah pegawai dan berbincang- 
bincang dengan keluarga pegawai tersebut sebagai bentuk rasa empati terhadap apa yang terjadi.

Para penyampai keputusan berusaha sebaik dan seprofesional mungkin dalam menyampaikan keputusan pemutusan hubungan kerja sehingga emosi negatif yang timbul bisa diminimalisir. Mereka melakukan beberapa usaha yang melibatkan target, yaitu pegawai yang akan dipecat dan orang-orang terdekat dari pegawai tersebut. Tidak hanya itu, terkadang penyampai keputusan juga melakukan beberapa tindakan dari dalam diri mereka atau secara internal untuk memperbaiki mood. Tindakan yang dilakukan bisa berupa menyendiri, minum kopi, bahkan memakan ice cream.

\section{Kesimpulan}

Emosi negatif adalah hal yang tidak dapat dihindari dari suatu proses rightsizing terumata pada para penyampai keputusuan pemutusan hubungan kerja. Dari hasil interview para responden yang pernah melakukan pemutusan hubungan kerja telah didapat kesimpulan mengenai emosi negatif yang muncul akibat proses tersebut. Mulai dari rasa bersalah (guilt) dikarenakan para penyampai keputusan tersebut merasa tidak kuasa untuk mencegah hingga pertimbangan yang lain terutama akan nasib para pekerja yang terkena dampak pemutusan hubungan kerja tersebut.

Rasa bersalah muncul pada awal-awal karir mereka seiring berjalannya waktu akan berkurang namun tetap ada rasa sedih ( $\mathrm{sad}$ ) yang timbul akibat rasa kasihan yang muncul akibat proses rightsizing yang berdampak pada nasib pekerja yang terkena pemutusan hubungan kerja. Selain itu juga terdapat rasa terganggu (annoyed) jika ada employee yang tidak sadar kenapa mereka termasuk salah satu yang terkena dampak karena biasanya atasan bekerja sama dengan divisi sumber daya dan pekerja yang berkinerja buruk menjadi prioritas.

Emosi negatif yang muncul akibat proses rightsizing terhadap para penyampai keputusan ini harus dihindari dikarenakan jika emosi negatif tersebut berdampak negatif pada para penyampai kerja maka berdampak buruk pada kinerja jika tidak segera diatasi. Cara bisa dilakukan untuk mengurangi emosi negatif tersebut antarai lain adalah dengan mendapat alasan yang kuat, karena rasa bersalah bisa timbul jika ada seuatu yang tidak benar dan dalam hal ini adalah normatif dan sesuai undang-undang maka rasa bersalah tersebut akan berkurang. Tindakan preventif dengan memberikan pengertian sebelumnya seperti membina dan memberi coaching juga menjadi alternative.

Tindakan lain yang bisa dilakukan untuk mengurangi emosi negatif adalah dengan menyesuaikan sesuai karakter dan lebih jauh bisa dengan melakukan pendekatan kepada orang orang terdekat pegawai sehingga diharapkan dapat memberi pengaruh positif baik bagi pekerja yang diberhentikan sekaligus bagi penyampai keputusan. Cara terakhir yang dapat dilakukan adalah dengan meningkatkan mood baik dilakukan oleh dengan memlakukan hal yang disuka seperti minum kopi atau sekedar ice cream. 
Fuad Firmansyah

\section{BIBLIOGRAFI}

Cameron, Kim S. (1994). Strategies for successful organizational downsizing. Human Resource Management, 33(2), 189-211. Google Scholar

Cameron, Kim S., Freeman, Sarah J., \& Mishra, Aneil K. (1993). Downsizing and redesigning organizations. Organizational Change and Redesign, 19-63. Google Scholar

Dibble, Jayson L., \& Levine, Timothy R. (2010). Breaking good and bad news: Direction of the MUM effect and senders' cognitive representations of news valence. Communication Research, 37(5), 703-722. Google Scholar

Dube, Laurette, Belanger, Marie Claude, \& Trudeau, Elyse. (1996). The role of emotions in health care satisfaction. Marketing Health Services, 16(2), 45. Google Scholar

Flanagan, John C. (1954). The critical incident technique. Psychological Bulletin, 51(4), 327. Google Scholar

Frost, Geoff dan Bryan Howienso. (2003). Accounting Theory (5th ed.). John Wiley \& Sons Australia, Ltd.

Grace, Debra. (2007). How embarrassing! An exploratory study of critical incidents including affective reactions. Journal of Service Research, 9(3), 271-284. Google Scholar

Greenhalgh, Leonard, \& Rosenblatt, Zehava. (1984). Job insecurity: Toward conceptual clarity. Academy of Management Review, 9(3), 438-448. Google Scholar

Hossain, Monirul Alam, \& Taylor, Peter J. (1998). An examination of audit delay: Evidence from Pakistan. Papers, 64, 1-16. Google Scholar

Izard, Carroll E. (1991). The psychology of emotions. Springer Science \& Business Media. Google Scholar

Jenkins, Jennifer M., \& Oatley, Keith. (1996). Emotional episodes and emotionality through the life span. In Handbook of emotion, adult development, and aging (pp. 421-441). Elsevier. Google Scholar

Lazarus, Richard S., \& Folkman, Susan. (1986). Cognitive theories of stress and the issue of circularity. In Dynamics of stress (pp. 63-80). Springer. Google Scholar

McGlone, Matthew S., \& Batchelor, Jennifer A. (2003). Looking out for number one: Euphemism and face. Journal of Communication, 53(2), 251-264. Google Scholar

Moleong, Lexy J. (2013). Metode Penelitian Kualitatif, Bandung: Remaja Rosdakarya. Mosal. Google Scholar 
Oatley, Keith, \& Jenkins, Jennifer M. (1992). Human emotions: Function and dysfunction. Annual Review of Psychology, 43(1), 55-85. Google Scholar

Porter, Michael E., \& Maulana, Agus. (1980). Strategi bersaing: Teknik menganalisis industri dan pesaing. Google Scholar

Saks, Alan M. (2019). Antecedents and consequences of employee engagement revisited. Journal of Organizational Effectiveness: People and Performance. Google Scholar

Usman, Binyam, Akbar, Raza Ali, Pradeepan, Mahendiaran, Khalil, Sajjad, Khattak, Mehwish, \& Ul Haq, Sheikh Moeen. (2008). Early Social Service Involvement May Decrease Inpatient Hospice Stays. Journal of Palliative Medicine, 11(9), 1186-1187. Google Scholar

Weakland, Janet H. (2001). Human resources hollistic approach to healing downsizing survivors. Organization Development Journal, 19(2), 59. Google Scholar

\section{Copyright holder:}

Fuad Firmansyah (2022)

First publication right:

Syntax Literate: Jurnal Ilmiah Indonesia

This article is licensed under:

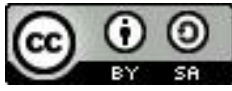

